\title{
Placental neutrophil count as an early predictor in neonatal sepsis
}

\author{
Nia Kania ${ }^{1}$, Ari Yunanto ${ }^{2}$, Pudji Andayani ${ }^{3}$, Iskandar ${ }^{4}$, Adelia Anggraini Utama ${ }^{5}$, Niarsari \\ Anugrahing Putri ${ }^{6}$, Ratih Kumala Sari ${ }^{7}$, Eko Suhartono ${ }^{8 *}$ \\ ${ }^{1}$ Department of Pathological Anatomy, Lambung Mangkurat University, Banjarmasin, Indonesia \\ 2, 3, 4, 5, 6, 7 Department of Child Health, Lambung Mangkurat University, Banjarmasin, Indonesia \\ ${ }^{8}$ Department of Medical Chemistry, Lambung Mangkurat University, Banjarbaru, Indonesia
}

\section{Keywords \\ Neonatal sepsis \\ Neutrophil \\ Oxidative stress \\ Placental}

Received: 1 January 2018

Accepted: 6 February 2018

Published: 26 February 2018

\begin{abstract}
This present study aims to assess the Placenta Neutrophil Count (PNC) as an early marker in the diagnosis of Neonatal Sepsis (NS). This study was conducted in February-May 2017. Cord blood samples and placental tissues were taken from 15 newborns at risk of sepsis (case group) and without risk of sepsis (control group). The PNC was estimated using a conventional light microscope. We also measured some oxidative stress parameters from the cord blood samples, i.e., hydrogen peroxide (H2O2), thiocyanate (SCN), myeloperoxidase (MPO) enzyme, and Advance Oxidation Protein Products (AOPPs) to investigate the role of neutrophil in the placenta. The results show that the PNC, the level of AOPPs and SCN, and MPO activity of cord blood were higher in the case group than the control group, while the $\mathrm{H} 2 \mathrm{O} 2$ level shows the opposite result. From these results, it can be assumed that neutrophils have a role in NS and might be used as a potential marker for the early prediction of NS. These findings need to be verified by further investigating fresh samples in a larger, prospective cohort and sophisticated analysis evidenced by deep sequencing. The placental pathologic and histologic examination has been used as a diagnostic tool for neonatologists in many neonatal diseases, except NS. This result suggested that PNC might be used as an early predictor for NS.
\end{abstract}

(C) 2018 The Author(s). Published by TAF Publishing.

\section{INTRODUCTION}

NS is a clinical syndrome manifested by immunoinflammatory disregulation as response to systemic bacteremia and still remains as the main cause of neonatal mortality and morbidity especially in developing countries $[1,2,3,4,5]$. The incidence of NS varies in each region. In United States at 2005, the incidence of NS was 3,5 to 8,9 per 1000 live birth while in Asia, it was 7,1 to 38 per 1000 live births [6, 7]. It was estimated around 1.6 million neonates died due to neonatal sepsis each year in developing countries, whereas this figure is less in developed countries. These indicate that the incidence of NS is higher in developed country [8]. Despite the incidence of NS has not been widely report, but some studies show it was around $1,5-3,72 \%$ with mortality rate $37-80 \%$ in several hospital in Indonesia at $2005[9,10]$

Neutrophilas a frontline defense for most acute infections, has an important role in neonates. In NS, neutrophil can be found to increase almost in all parts of neonates i.e., blood, saliva and also placental tissue. It shown in our previous study that the neutrophils number in saliva is higher in neonates with risk of sepsis [11]. Blanc et al also described that in infected condition, especially in NS, the neutrophil migrates into placental tissue. It seen from the increase of neutrophil count in neonatal placental tissue with risk of sepsis $[12,13,14]$.

As a response to invading infectious agent, neutrophils activated to form reactive oxygen compoundssuch as superoxide anion $(\bullet 02)$, Hydrogen Peroxide $\left(\mathrm{H}_{2} \mathrm{O}_{2}\right)$ and hydroxyl radicals $(\bullet \mathrm{OH})$. Beside, Myeloperoxidase (MPO) which is

\footnotetext{
${ }^{*}$ corresponding author: Eko Suhartono

†email: ekoantioxidant@gmail.com
} 
secreted by the neutrophils use $\mathrm{H}_{2} \mathrm{O}_{2}$ to catalyses the oxidation of thiocyanate (SCN) to form HOSCN to kill invading pathogens. Furthermore, this process resulting in the formation of oxidized protein known as Advance Oxidation Protein Products (AOPPs). Our previous studies suggested that MPO, $\mathrm{H}_{2} \mathrm{O}_{2}$, SCN and AOPPs can be used as a marker in blood sample and salivary of the newborns at risk of sepsis due to oxidative stress process in NS $[11,15]$.

One of the main problems in the management of NS is getting an accurate and rapid diagnosisbecause the antibiotics treatment should initiated as soon as possible. Blood culture as gold standard to diagnose NS still lacks because it takes time, expensive and obtaining cultures from neonates can be difficult $[16,17]$.This recent years, some marker has been proposed to diagnose NS, but still it has many shortcomings.

In this study, we propose a potential marker to diagnose NS by PNC using a microscopic examination which is low cost, easy to do and faster to perform. It based on the role of neutrophils migration into placentaas mentioned earlier [18]. To confirm this migration, we also measured some oxidative stress parameters i.e., $\mathrm{H}_{2} \mathrm{O}_{2}$, $\mathrm{SCN}$, MPO and AOPPs in cord blood samples which is produced by neutrophil during infection condition.

\section{MATERIAL AND METHODS}

\section{A. Subjects}

This study was conducted in newborn with and without risk of sepsis after informed consent was obtained. It was approved by the Ethics Commission of the Faculty of Medicine, Lambung Mangkurat University, Banjarmasin, South Kalimantan, Indonesia. This research was conducted from February to May 2017 in the Neonatology Division, Department of Pediatric, Ulin General Hospital/Faculty of Medicine, Lambung Mangkurat University, Banjarmasin, South Kalimantan, Indonesia. All histological finding were conducted at Department of Pathology Anatomy of Faculty of Medicine Lambung Mangkurat University/Ulin General Hospital, Banjarmasin, South Kalimantan, Indonesia. Blood sample tests were conducted at Department of Medical Chemistry/ Biochemistry, Faculty of Medicine Lambung Mangkurat University, Banjarbaru, South Kalimantan, Indonesia.

A total of 30 infants subjects were recruited for this study. Subjects were divided into 2 groups: group I were newborns at risk of sepsis and served as a case group, while group II were newborns without risk of sepsis and served as a control group. Subjects in the sepsis risk group were included on the basis of having at least 1 major criteria or 2 minor criteria for sepsis according to The American Congress of Obstetricians and Gynecologist (ACOG) guidelines $[1,19]$.

\section{B. Samples Collecting Procedure}

Blood samples were taken from umbilical cord ( $5 \mathrm{ml}$ each) and collected using vacutainers containing EDTA. The samples were centrifuged for $15 \mathrm{~min}$ at $2000 \mathrm{rpm}$ and stored at -20C until further analysis. Placental tissues were taken in an area $10 \mathrm{~cm}$ from the base of umbilical cord and cut using steril scalpel/scissor. The tissues were stored in a tube containing buffer formalin $10 \%$. Wet fixation is used as a sample delivery method to pathology anatomy department.

\section{Histological Analysis}

Placental tissues stained with hematoxylin and eosin (HE). Neutrophils count were performed using conventional light microscope in 40X objective lens. Average neutrophils count were taken at 10 fields of view.

\section{Oxidative Stress Parameters Analysis}

AOPPs concentration analysis measurement was measured spectrophotometrically at $\lambda=340 \mathrm{~nm}$ as describe by [15]. $\mathrm{H}_{2} \mathrm{O}_{2}$ level was measured spectrophotometrically at $\lambda=505$ $\mathrm{nm}$ by FOX2 method.17 SCN concentration was measured spectrophotometrically at $\lambda=450 \mathrm{~nm}$ as described [15]. MPO activity was measured spectrophotometrically at $\lambda=$ $470 \mathrm{~nm}$. One unit (U) of MPO activity was defined as that degrading $1 \mu \mathrm{mol}$ of $\mathrm{H}_{2} \mathrm{O}_{2}$ per minute at $25^{\circ} \mathrm{C} .18$

\section{E. Statistical Analysis}

Data are presented as $M \pm S . D$. The comparison of PNC in each group were examined by Independent $\mathrm{T}$ Test and for AOPPs, $\mathrm{H}_{2} \mathrm{O}_{2}$, SCN levels and MPO activity were examined by Mann Whitney Test. For all outcomes, a nominal p-value of $p<0.05$ was considered significant. Data analysis using the Statistical Package for the Social Sciences (SPSS) version 16.0 andMicrosoft Excel 2010 for Windows 10.

\section{RESULTS AND DISCUSSION}

This present study aims to investigate a potential marker of NS. This potential marker is thenumber of neutrophil counts on the PNC. The PNC result shows in Figure 1. According to Figure 1, the mean of PNC is higher in case group than the control group $(p<0.05)$. This result is similar to observation made by Varea et al who reported that the neutrophils count is significantly higher in patient with microorganisms found in amniotic fluid than in those without detectable microorganism [20]. 
The increasing of PNC in the case group might be caused by neutrophil migration in NS. It is well known that the NS is caused by chorioamnionitis. When the pathogens enter to amniotic fluid causing chorioamnionitis through placental membrane, an acute inflammatory lesion occurs in the placenta. This lesion marked by the migration of neutrophils due to the chemotactic gradient from the intervillous space into the chorionic plate which is normally devoid of this cells [12].

To confirm the increasing of neutrophil in NS, we also measured the MPO activity in cord blood sample. When the neutrophil increased, it followed by the increasing of MPO activity. This enzyme is secreted by neutrophil which is very important to determine further process to kill the invading pathogen [21]. This is in line with the result of this present study (Figure 2). From the results, MPO activity is higher in case group than the control group $(p<0.05)$. This result was also supported by our previous study which shows the significant increase of MPO activity in newborn with risk of sepsis.

The increasing of MPO activity are intending to kill the invading pathogen by utilized $\mathrm{H}_{2} \mathrm{O}_{2}$ to catalyses the oxidation of SCN to form HOSCN, a highly toxic substance to kill pathogen. This is consistent with the result in this study (Figure 3). The result from the Figure 4 shows that the SCN level is higher significantly in the case group $(p<0.05)$.In ad- dition, this result was also supported by our previous study which showsthat the SCN level is increase significantly in blood of newborn with risk of sepsis.

Figure 4 show that the level of $\mathrm{H}_{2} \mathrm{O}_{2}$ are decreased but it is not significant $(p>0.05)$.It is different with study conducted by [21]. which shows that the $\mathrm{H}_{2} \mathrm{O}_{2}$ level is higher in saliva and blood of newborn with risk of sepsis. The decreasing of $\mathrm{H}_{2} \mathrm{O}_{2}$ level in this study seems like because of $\mathrm{H}_{2} \mathrm{O}_{2}$ is widely used by MPO in sepsis condition to generate the HOSCN. The MPO not only utilizes $\mathrm{H}_{2} \mathrm{O}_{2}$ and $\mathrm{SCN}$ to form HOSCN, but also $\mathrm{H}_{2} \mathrm{O}_{2}$ with other co-substrate such as $\mathrm{Br}$-and I-to form hypobromous ( $\mathrm{HOBr}$ ) and hypoiodous (HOI) so there is a decrease in $\mathrm{H}_{2} \mathrm{O}_{2}$ level [22].

The HOSCN that produced in sepsis condition not only play role in killing the invading pathogen, but also promote a host tissue damage such as the protein oxidation. AOPP is already known as one of the oxidized protein and has been used as oxidative stress marker for several disease such as NS [23]. The AOPP level measurement in both case and control group shows in Figure 4. The result clearly indicated that there is a significant increase of AOPP level in case group $(p<0.05)$. Also, this result is in line with our previous studyresult that shows the increasing of AOPP level but in blood of newborn with risk of sepsis.8In addition, all these processes are describe in Figure 5.

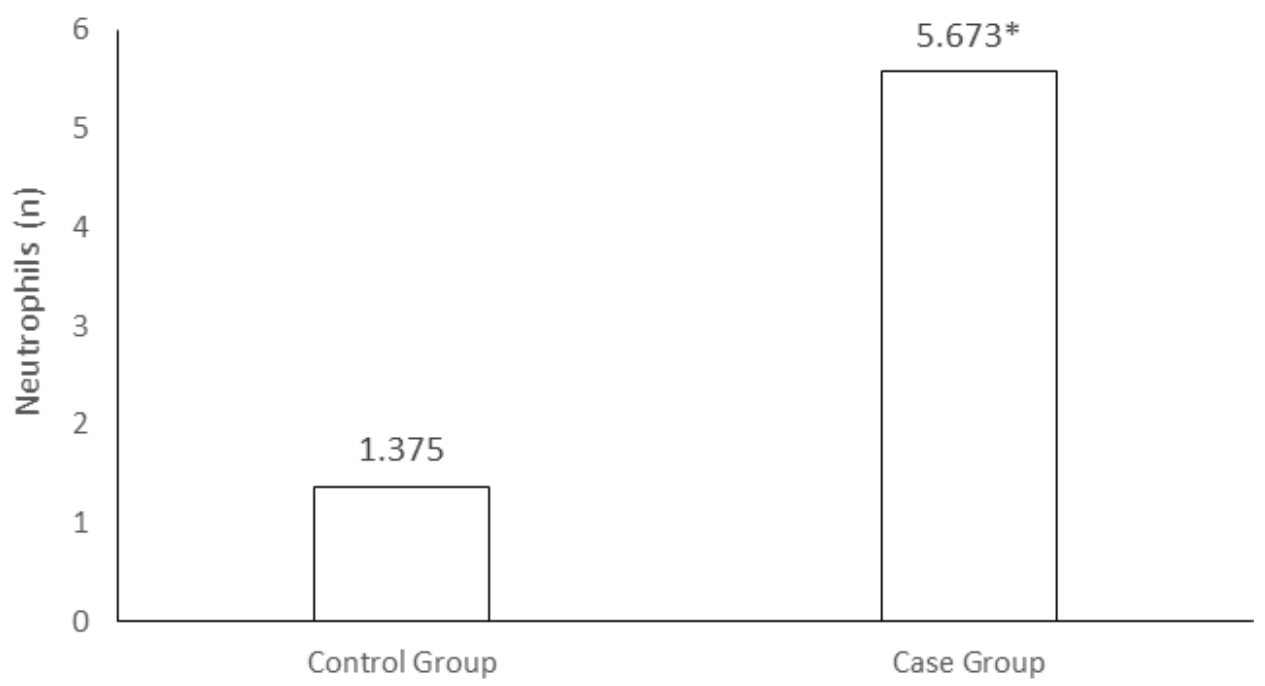

Fig. 1. Comparison of PNC between group using Independent $T$ Test

Data are presented as $M \pm S$.D. Statistical significance ${ }^{*} p<$ 0.05 with in comparison with control group. Data are presented as $M \pm S . D$. Statistical significance ${ }^{*} p<0.05$ with in comparison with control group. Data are presented as $M$ \pm S.D. Statistical significance ${ }^{*} p<0.05$ with in comparison with control group. Data are presented as $M \pm S$.D. Statistical significance ${ }^{*} p<0.05$ with in comparison with control group. 


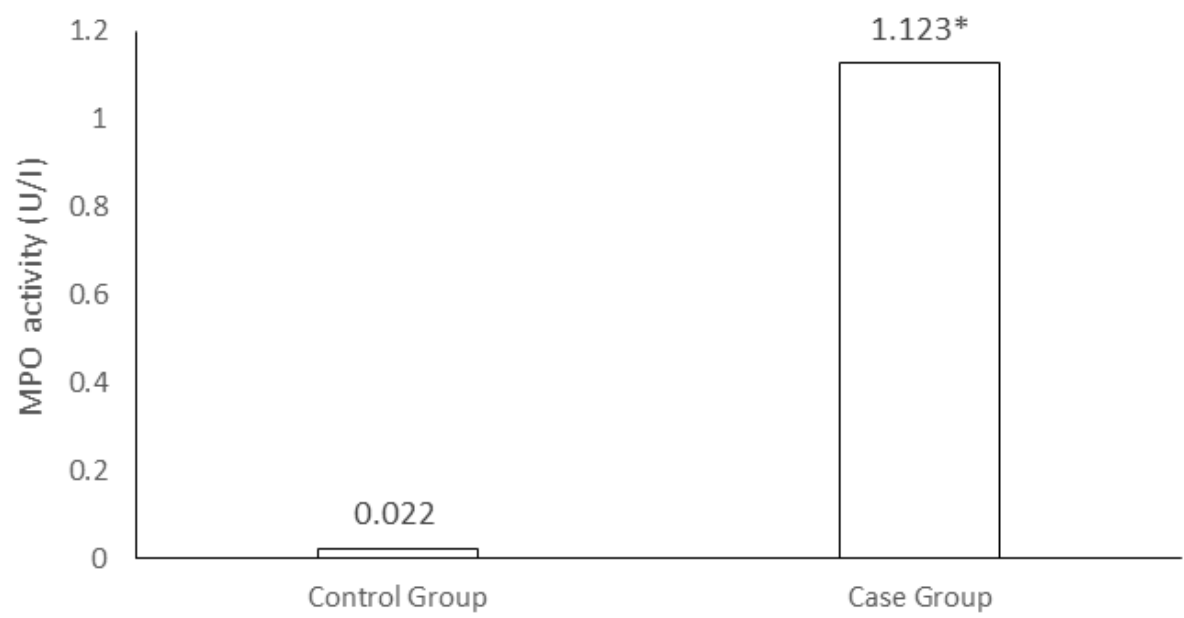

Fig. 2. Comparison of MPO activity between group using mann-whitney test

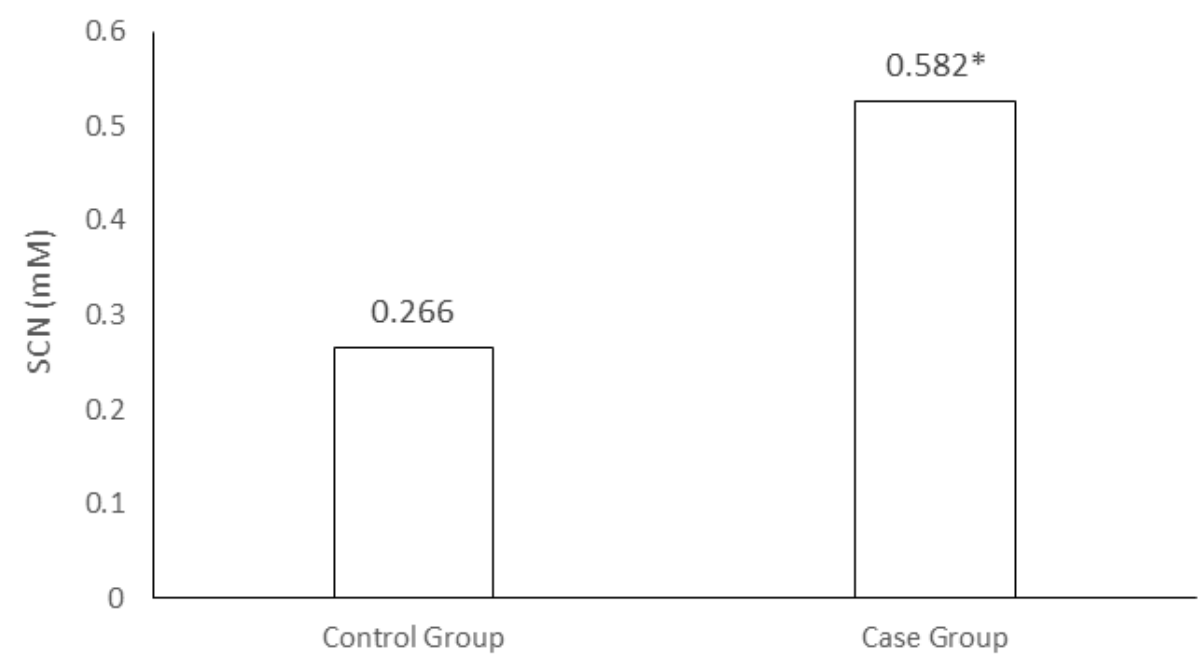

Fig. 3. Comparison of SCN level between group using mann-whitney test

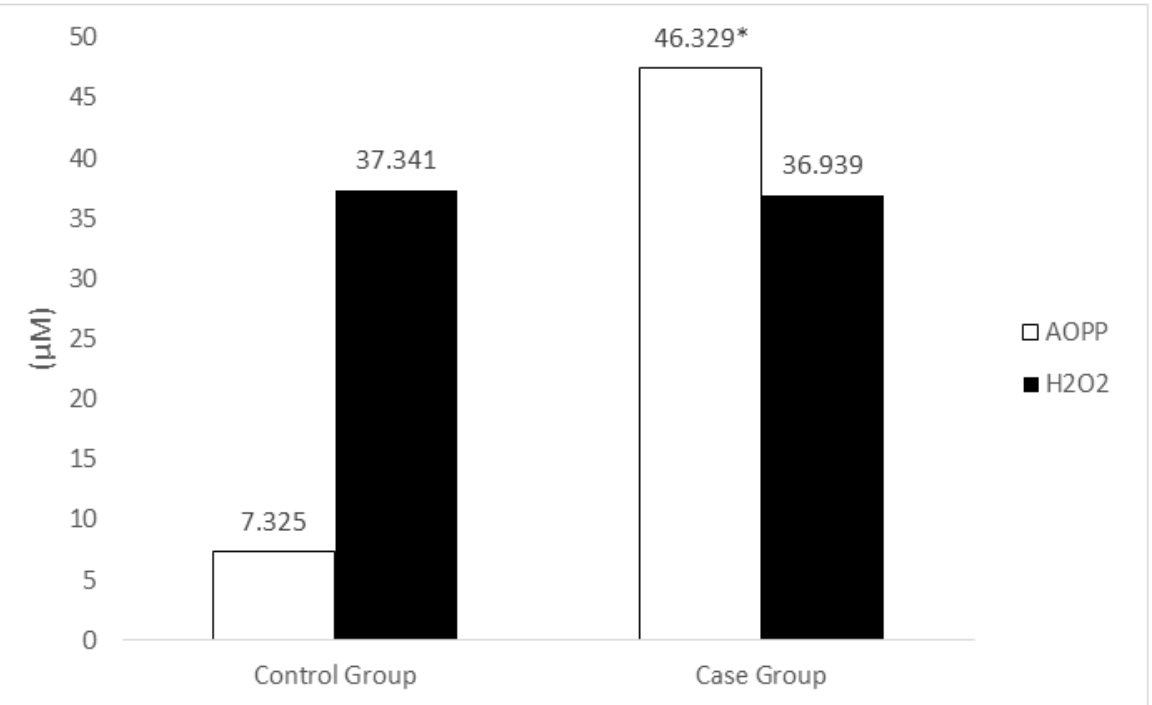

Fig. 4. Comparison of AOPPs and $\mathrm{H}_{2} \mathrm{O}_{2}$ level between group using mann-whitney test 


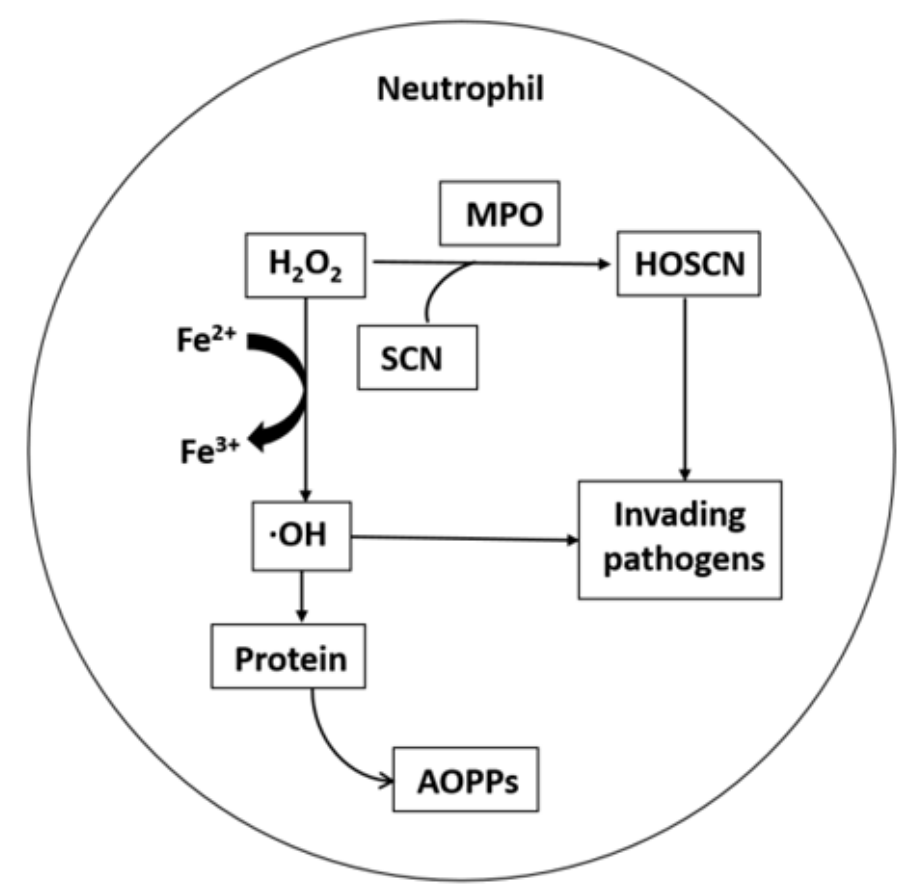

Fig. 5. Oxidative stress mechanism in NS

\section{CONCLUSION}

From this result, it can be concluded that the PNC might be use as a potential marker for early prediction of NS. These findings need to be verified by further investigation with a larger and fresh samples, using a prospective cohort study, and with sophisticated analysis evidenced by deep sequencing.

\section{REFERENCES}

[1] Sankar MJ, Agarwal R, Deorari AK, Paul VK. Sepsis in the newborn. The Indian Journal of Pediatrics. 2008;75(3):261-266. doi: https://doi.org/10.1007/s12098-008-0056-z.

[2] Charles M, Kalaivani R, Venkatesh S, Kali A K Seetha. Evaluation of procalcitonin as a diagnostic marker in neonatal sepsis. Indian Journal of Pathology and Microbiology. 2018;61(1):81-84. doi: https://doi.org/10.4103/ijpm.ijpm_820_ 16.

[3] Rochmah EN, Haksari EL, Mulatsih S. Association between neutropenia and death rate of bacterial neonatal sepsis. Paediatrica Indonesiana. 2008;48(5):284-287. doi: https://doi.org/10.14238/pi48.5.2008.284-7.

[4] Naido P. Evaluation of clinics on the provision of youth friendly services in the Ethekwini Metro of Kwazulu Natal. International Journal of Health and Medical Sciences. 2015;1(1):1-7. doi: https://doi.org/10.20469/ijhms.30001.

[5] Aloofy TA, Al-Ansary L, Mokhlis LG, Khalil NK, Abo Alsamh NH, Faden NA, et al. Public knowledge and practice of sore throat management among visitors of primary care clinic in Riyadh, Saudi Arabia. Journal of Advances in Health and Medical Sciences. 2017;3(2):1-8. doi: https://doi.org/10.20474/jahms3.1.1.

[6] Shaha CK, Dey SK, Shabuj KH, Chisti J, Mannan M, Jashimuddin M, et al. Neonatal sepsis a Review. Bangladesh Journal of Child Health. 2012;36(2):82-89. doi: https://doi.org/10.3329/bjch.v36i2.13084.

[7] Kittichottipanich B, Yingpaiboonsook U, Somsauy P, Kositwon S. Model of health promotion for reducing risky behaviors of preterm birth in teenage pregnancy. International Journal of Health and Medical Sciences. 2016;2(1):20-26. doi: https://doi.org/10.20469/ijhms.2.30004-1.

[8] Silva N, Menerez R, Brito M, Alves P, Pedroso R, Roder D. Sepsis neonatal: Epidemiology, etiology and risk factors. Advances in Biotechnology \& Microbiology. 2017;4(2):1-23. doi: https://doi.org/10.19080/aibm.2017.04.555632.

[9] Utomo MT. Neonatal sepsis in low birth weight infants in Dr. Soetomo general hospital. Indonesian Journal of Tropical and Infectious Disease. 2010;1(2):86-89. doi: https://doi.org/10.20473/ijtid.v1i2.2172.

[10] Simarmata YBC, Harahap U, Djipta G. Identification of risk factors caused neonatal sepsis of prem ature neonatus in Adam Malik general hospital center. Birth. 2016;5:25. 
[11] Yunanto A, Firdaus RT, Suhartono E. Advance Oxidation Protein Products (AOPPs) of newborn at risk of sepsis as novel parameter for early-onset neonatal sepsis. International Journal of Bioscience, Biochemistry and Bioinformatics. 2014;4(2):90. doi: https://doi.org/10.7763/ijbbb.2014.v4.317.

[12] Kim CJ, Romero R, Chaemsaithong P, Chaiyasit N, Yoon BH, Kim YM. Acute chorioamnionitis and funisitis: Definition, pathologic features, and clinical significance. American Journal of Obstetrics and Gynecology. 2015;213(4):S29-S52. doi: https://doi.org/10.1016/j.ajog.2015.08.040.

[13] Rosenblum J. Placental pathology and fetal inflammatory response to infection. Physician Insurer. 2009;4(1):46-49.

[14] Redline RW, Faye-Petersen 0, Heller D, Qureshi F, Savell V, Vogler C, et al. Amniotic infection syndrome: Nosology and reproducibility of placental reaction patterns. Pediatric and Developmental Pathology. 2003;6(5):435-448. doi: https://doi.org/10.1007/s10024-003-7070-y.

[15] Yunanto A, Iskandar SE. In-vitro effects of some antibiotic drugs on saliva thiocyanate and oxidation protein products levels on newborn at risk of sepsis. International Journal of Pharmaceutical and Clinical Research. 2016;8(1):86-89. doi: https://doi.org/10.7763/ijbbb.2014.v4.317.

[16] Mulyani A, Setyowireni S, Surjono A. Diagnostic accuracy of clinical and blood examination for sepsis in potentially infected neonates. Paediatrica Indonesiana. 2002;42(9-10):220-224. doi: https://doi.org/10.14238/pi47.6.2007.283-9.

[17] Cobo T, Kacerovsky M, Andrys C, Drahosova M, Musilova I, Hornychova H, et al. Umbilical cord blood IL-6 as predictor of early-onset neonatal sepsis in women with preterm prelabour rupture of membranes. PloS One. 2013;8(7):e69341. doi: https://doi.org/10.1371/journal.pone.0069341.

[18] Yallapragada SG, Mestan KK, Ernst LM. The placenta as a diagnostic tool for the neonatologist. Neo Reviews. 2016;17(3):e131-e143. doi: https://doi.org/10.1542/neo.17-3-e131.

[19] Bryce J, Boschi-Pinto C, Shibuya K, Black RE, Group WCHER, et al. WHO estimates of the causes of death in children. The Lancet. 2005;365(9465):1147-1152. doi: https://doi.org/10.1016/s0140-6736(05)71877-8.

[20] Martinez-Varea A, Romero R, Xu Y, Miller D, Ahmed AI, Chaemsaithong P, et al. Clinical chorioamnionitis at term VII: The amniotic fluid cellular immune response. Journal of Perinatal Medicine. 2017;45(5):523-538. doi: https://doi. org/10.1515/jpm-2016-0225.

[21] Yunanto A, Andayani P, Triyawanti, Suhartono E, Widodo A. Neutrophil phagocytosis activity compared to myeloperoxidase, hydrogen peroxidase and lactoferrin levels in saliva of newborn baby with sepsis risk factors to detect early-onset neonatal sepsis. International Journal of Pharmaceutical Science Invention. 2013;2(1):18-22.

[22] Rao AM, Anand U, Anand C. Myeloperoxidase in chronic kidney disease. Indian Journal of Clinical Biochemistry. 2011;26(1):28-31. doi: https://doi.org/10.1007/s12291-010-0075-1.

[23] Suhartono E, Yunanto A, Hartoyo E, Kania N, Utama AA, Sari RK, et al. UV-visible spectrophotometric as a prospective tool in neonatal sepsis. The Indonesian Biomedical Journal. 2018;10(1):74-78. doi: https://doi.org/10.18585/inabj. v10i1.360. 